
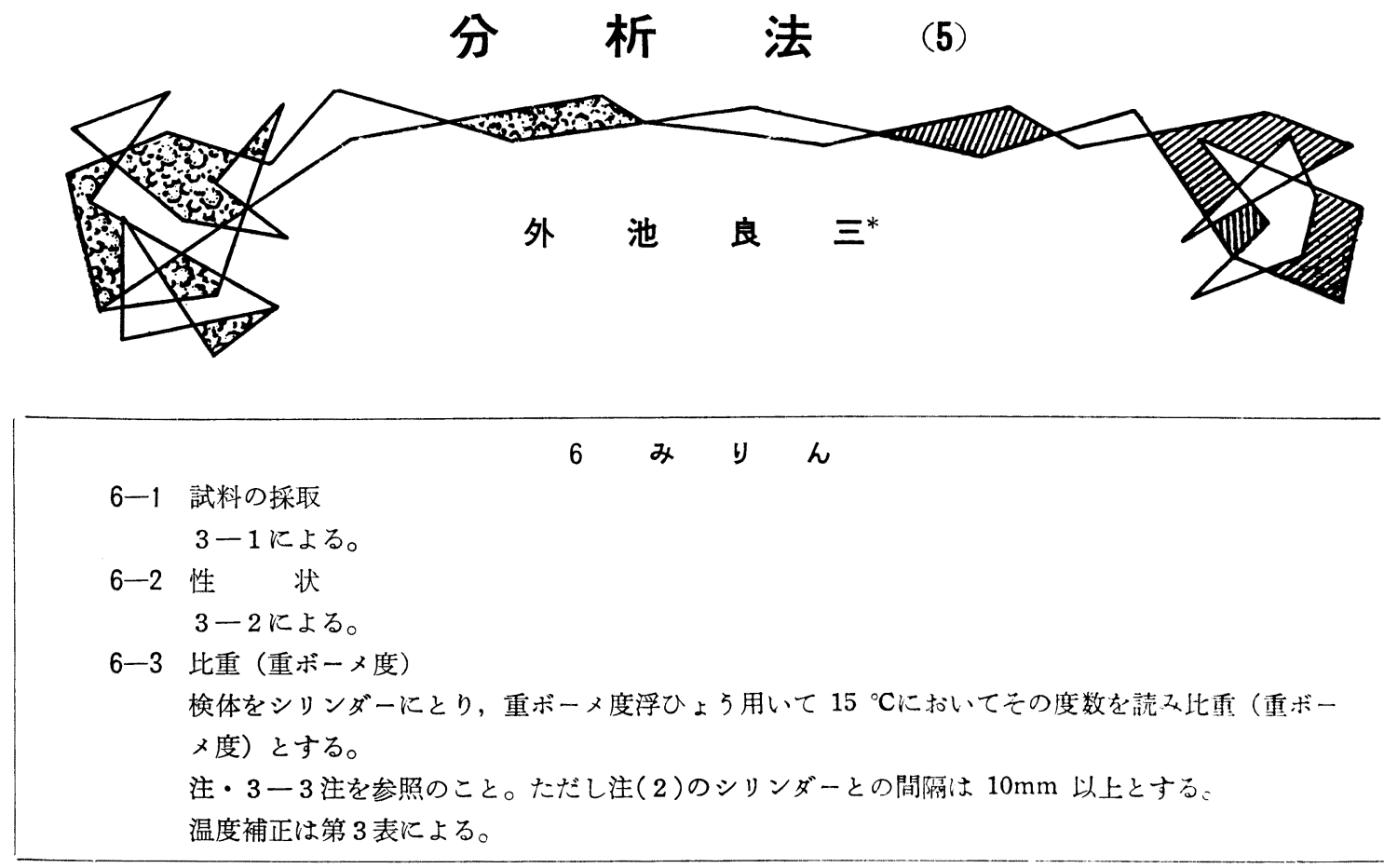

\section{比重（重ボーメ度）}

みりんの比重は重ボーメ度浮ひょらを用いて測定する。 注で示してあるように，みりん特に甲類は粘度の高い ものであるから，シリンダーと浮ひょうとの間隔は，今 までの酒類と異って $10 \mathrm{~mm}$ 以上なければならない。 温度補正の精度は日本酒度の場合と同様である。 な扮重ボーメ度浮ひようの検定公差，使用公差は次の
通りである。

\section{1 目盛の值検定公差使用公差}

0.1 重ボーメ度以下 0.1 重ボーメ度 0.1 重ボーメ度
$0.2 \prime \prime$
0.2 "
$0.2 "$
"l

$0.5 \prime$

$0.5 \prime \prime$

$0.5 \prime$

11

1 "゙をこ究るき 2

\title{
6-4 アルコール分
}

3ー4 亿よる。ただし甲類は検体 $50 \mathrm{~m} l$ を採取し毎回約 $20 \mathrm{~m} l$ の水で 2 回洗い，留液約 $50 \mathrm{~m} l$ を とり水を加えて $100 \mathrm{~m} l$ として測定し，この数值を 2 倍してアルコール分の度数とする。

アルコール分

清酒，合成清酒の場合にならって行うのが本則である が，甲類は粘度が高いので検体を $50 \mathrm{ml}$ とり洗い水の量 を多くして合計約 $40 \mathrm{~m} l$ で洗い, 留液を $50 \mathrm{ml}$ とる。こ のまま浮ひょうで測定できればいいが，小型の浮ひょう
はどらしても精度がおち易いので，算用の $100 \mathrm{ml}$ 用程

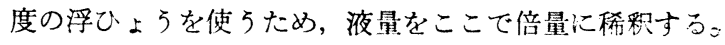
この所が少し原則にはずれることになるが、現在の計器 等から考えると止むを得ない。そこで当然真の值は舀測 值の倍になる。乙類の場合は $3-4$ の通引行之代い:

\section{6一-5 エキス分}

甲類は次式によって算出する。

$$
E=\{(S-A) \times 260 \times 0.21\} \times 2 \quad \text { （小数点以下 } 2 \text { 倍を切り拾てる） }
$$

ただし $E$ はエキス分, $S$ は倍量に希釈した検体について7ー5により測定した此重, $A$ 法6-4 により湘定したアルコール分度数（2 倍しないもの）を第 5 表により比重 $\left(15 / 15^{\circ} \mathrm{C}\right)$ に換算したもの。 乙類は $7-7$ によ。 
酒類のエキス分測定については, 一通り $3-7$, 清酒 合成清酒のエキス分1)に执い解説を行った。みりんにつ いても直接法を行わず，間接法すなわち酒類の比重とア ルコール分から，ある一定の式によって算出しようとす る方法を採用した。ただしみりんの場合の算出式は, 清 酒, 合成清酒の場合と異っている。これについては, 川 島息が詳しく報告解説を行っている。

ただみりん甲類のような濃厚なものについては，（現 在の規格重ボーメ度 19，アルコール分 13 度）エキス分 としては 40 以上の数字になるので, このようなものは むしろ希釈をして測定するが正しい数字が得られると考 える。従って，このエキス計算式は\{ \}内が基本式で， これの値を倍することになっている。

\section{間接法の根奶}

くりかえしていらように間接法の根拠は次のように要 約される。

（1）あらゆる酒類のエキス分は，糖類がその大部分 を占め，その他の成分は極微量で，エキス分即糖分と考 えても普通の場合は差支えない。非常に精密を要求する 場合は別である。なおその糖分はしょ糖を代表させても 誤りでない。

（2）しょ糖水溶液の比重とエキス分との関係を示し たのは，Windisch 表1である。この表は古くから世 界各国でも用いられ，我が国の中央計重検定所でしょ糖 分の比重として採用している Landolt 表と一致してお。 る。またこの表は比重と重量/容量％の関係が直線的で 算式をつくるのに便利である。

（3）酒類の揮発性物質を除き，水で原容に復したも のの比重がわかれば, 前記の Windisch 表を引くこと によって, その比重に拈けるしょ糖水溶液としての重量 / 容量\%がわかる。この値を酒のエキス分としても， （1）（2）の根拠婂大き誤りがない限り差支えない。 以上の 3 つの点が間接測定法の根本である。すちろん 直接法が基礎になることはいらまでもないが，直接法は 高度の技術と熟練を要するもので，特に問題点は検体を 濃樎乾燥する過程である。赤外線乾燥のよ5なものが出 てはいるが，必ずしも正確とはいい難い。ところで酒類 の比重とアルコール分を測ること自体は，もちろん決し て容易なことではないが，少くとも直接法よりは万人向 きであり，時間を要しない。また酒類の場合，エキス分 丈を测定するといらことは，まず実際仙はないとで, 比重やアルコール分は常に测っていることなので，この 数値を用いた算式に上る間接法は便利である。比重を浮 ひょうで読むのは 0.001 までは大抵は間違いなく読め るもので，上手にやれば 0.0005 までは見られる。この 数字はエキスとして 0.13 であるから, 直接法と比較し てさ程精度は拈ちていない3)。

エキス算定式について $E=(S-A) \times 260+0.1$
3-7 の解説にあげてある Windisch 表1)簡単に した附表 1 を見ると, 比重 0.001 はエキス分 0.258 0.260 の間にあり，これを一般式で表わすと比重から 1 を減じた数值にある係数（258～260）を乗ずればエキス 分がるとめられることになる。

\section{附 表 1}

$\begin{array}{lcc}\text { 比重 } & \text { エキス } \mathrm{g} / \mathrm{m} l & \text { 差 } \\ 1,000 & 0.00 & \\ 1,0010 & 0.26 & 0.2600 \\ 1,0100 & 2.56 & 0.2580 \\ 1,0200 & 5.17 & 0.2585 \\ 1,0300 & 7.76 & 0.2587 \\ 1,0400 & 10.35 & 0.2588 \\ 1,0500 & 12.95 & 0.2590 \\ 1,0600 & 15.55 & 0.2592 \\ 1,0700 & 18,16 & 0.2594 \\ 1,0800 & 20.78 & 0.2598 \\ 1,0900 & 23.41 & 0.2601 \\ 1,1000 & 26,04 & 0.2604\end{array}$

すなわちエキスを小数点以下一位までとすると, 乗ず る係数は三位まででよく，258，259，260の 3 ケのうち から選べばよいことになる。今これらの数字をあてはめ てみると附表 2 のよ5になる。

\section{附 表 2}

\begin{tabular}{lrrrr} 
比重 & エキス & \multicolumn{1}{c}{258} & 259 & 260 \\
1,0000 & 0.00 & 0.00 & 0.00 & 0.00 \\
1,0010 & 0.26 & 0.26 & 0.26 & 0.26 \\
1,0100 & 2.58 & 2.58 & 2.59 & 2.60 \\
1,0200 & 5.17 & 5.16 & 5.18 & 5.20 \\
1,0300 & 7.76 & 7.74 & 7.77 & 7.80 \\
1,0400 & 10.35 & 10.32 & 10.36 & $10 \cdot 40$ \\
1,0500 & 12.95 & 12.90 & 12.95 & 13.00 \\
1,0600 & 15.55 & 15.48 & 15.54 & 15.60 \\
1,0700 & 18.16 & 18.06 & 18,13 & 18.20 \\
1,0800 & 20.78 & 20.64 & 20.72 & 20.80 \\
1,0900 & 23.41 & 23.22 & 23.32 & 23.40 \\
1,1000 & 26.04 & 25.80 & 25.90 & 26.00
\end{tabular}

この表でみるように 258 とすると比重 1.01 まではよ く一致するが 1.02 からは差ができ始め, 1.1 では 0.2 程差ができる。259 とすると 1.08 から幾らか差ができ 1.1 で 0.1 程の差になる。260 亿すると比重 1.06 まで は \pm 0.05 以内の差があるが, 比重が多くなっても前の 2 つのよ 5 にる小数点以下 1 桁に差は出てこない。この ような点から, エキス $E$ は

$$
E=(d-1) \times 260
$$

さてこの $d$ をとめること, つまりしょ糖水溶液の比 重, すなわち前記の ( 3 )根拠, 揮発性物質を除いて水で 原容に減じたものの比重をどのようにしてもとめるか が, 次の問題である。 


\section{$97(501)$}

これについては 3-7 の解説で示した鹿又等4の此重 をもとめる式があるが，これはアルコールと水と混合の 際に生ずる収縮を考虑に入れてあって，やや複雑である のと, 収縮率にかなりフレがあり,アルコール分を一定 にしないと(この式では一応清酒が中心なるので 17 度) 通用しないことになり，一般的ではない。川島等》はと こで次の式を提案した。

$$
d_{e 15}^{15}=\left(d_{s 15}^{15}-d_{a 15}^{15}\right)+1
$$

ただし $d_{e 15}^{15}$ : 水で原容に復した溶液の比重 $15 /\left[5^{\circ} \mathrm{C}\right.$ $d_{s 15}^{15}$ : 酒の $15 / 15^{\circ} \mathrm{C}$ の比重 $d_{a 15}^{15}:$ 酒のアルンール分の $15 / 15^{\circ} \mathrm{C}$ の比重 この式を川島は次のよ5に説明している。(第1目) $\mathrm{A}$ の容器に酒 $100 \mathrm{~m} l$ が入っている。この酒のアルコ 一ルの容量を $a$, エキスの重量を $E$, このエキスが酒 中で占める容量を $E_{v}$ とすると, 水は $100-a x-E_{v}$, た だし $x$ はアルコールがエキスを含有した液と混和した時 の収縮を考党た係数。

次にこの $A$ の酒を蘶発させ, 揮発性物質を $\mathrm{B}$ の容器 にとると, この中にはアルコール $a$ と水 $100-a x-E_{v}$ があることになる。これを原容に復するためには, エキ

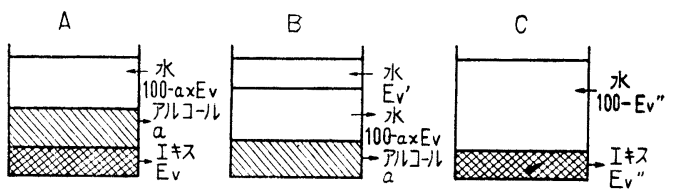

スの容量 $E_{v}$ 丈を加えてたのではいけない。つまり $A$ のようにエキスのある状態と $B$ のように水だけの場合 とはアルコールの収縮は異るのであるから, 加觉る水は $E_{v}+Z=E_{v}{ }^{\prime}$ となる。

Cは $A$ に残ったエキスだけに水を加えて原容に復す ることを示したもので，この場合加える水の量はどうな るか。まず $E$ が酒にとけている時の容磧は $E_{v}$ であった が，これが水だけに溶解するときの占める容積は, 幾分 異って抢り， $E_{v}{ }^{\prime \prime}=E_{v}+Z^{\prime}$ となる。加党る水の量は 100 一 $E_{v}$ となる。

つまり $A$ のアルコール分とエキス分を，Bにアルコ ール，Cにェキスだけを分けると，

$$
\begin{aligned}
& B \text { には } 100-a x-E_{v}+E_{v}{ }^{\prime} \\
& C \text { には } 100-E_{v}{ }^{\prime \prime}
\end{aligned}
$$

の水を加えれば，それぞれ原容に復する訳である。こ の水量の合計 $\left(100-a x-E_{v}\right)+E_{v}{ }^{\prime}+100-E_{v}{ }^{\prime \prime}$

のうち $100-a x-E_{v}$ は始めからの酒中の水であるから, 新らしく加党る水の量は,

$$
100+E_{v^{\prime}}-E_{v^{\prime \prime}}
$$

そころでェキスのある水溶液にアルコールを加えた場
合と，ただの水にアルコールを加えた場合の収縮量の差 すなわち $E_{v}{ }^{\prime}-E_{v}{ }^{\prime}=Z$ は普通の場合はごく小さい值で あり，エキスをアルコールにとかした場合と水にとかし た場合の溶解実績の差，すなわち $E_{v}{ }^{\prime \prime}-E_{v}=Z^{\prime}$ はきわ めて小さいので,

$$
E_{v} \doteqdot E_{v}{ }^{\prime}=E_{v}{ }^{\prime \prime} \quad E_{v}{ }^{\prime}=E v^{\prime \prime}
$$

となり新たに加兄る水の量は（5)を（4）に入れることに より $100 \mathrm{ml}$ となる。

今始めの $A$ の酒の此重を $d_{s}, B$ のアルニール溶液の 比重を $d_{a}, C$ のエキス水溶液の比重を $d_{e}$, 新たしく加. える水の量を $d_{w}$ とすると $A, B, C$, および新たに加方 た水の量は $100 \mathrm{~m} l$ であるから, 次の式が成り立つ。

$$
100 \times d_{a}+100 \times d_{e}-100 \times d_{w}=100 \times d_{s}
$$

( $B$ の重量) ( $C$ の重量) (加兄た水の重最) ( $A$ の重量)

$$
\begin{aligned}
& d_{a}+d_{e}-d_{w}=d_{s} \\
& \quad d_{e}=d_{s}-d_{a}+d_{w}
\end{aligned}
$$

これらを $15 / 15^{\circ} \mathrm{C}$ で测定すると

(6)式は $\quad d_{e 16}^{15}=\left(d_{s 15}^{15}-d_{a 15}^{15}\right)+1\left(\because d_{w 16}^{15}=1\right)$

となり (3)式となる。

(3)式を(2)式に代入すると,

$$
E=\left(d_{s 15}^{15}-d_{a 16}^{15}\right) \times 260
$$

この $(7)$ 式は, 酒の比重とアルコール分の比重が分ボ ばエキス分が計算でもとめられる訳である。

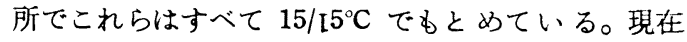
の比重は $15 / 4^{\circ} \mathrm{C} て ゙$ 裴わされているので，これを $15 / 15^{\circ} \mathrm{C}$ に換算しなくてはならない。 $d_{s}^{15}$ を $d_{s 15}^{15}$ 深算するに は $d_{s 4}^{15} \times 1,00087$ である。

$d_{s 4}^{15}$ は $0.960 \sim 1.1100$ の範田とすると, 平均值は 1,0350 になり，また係数を 260 にしたためにおこる䛊 差を 0.02 程多く出ると考之(附表 2 ), この補正を( 7 ) 式行 5 と

$$
\begin{aligned}
&\left(d_{s 4}^{15} \times 1,00087-d_{a 15}^{15}\right) \times 260-0.02 \\
&=\left(d_{s}^{15}-d_{15}^{15}\right) \times 260+0.226 \times d_{s 4}^{15}-0.02 \\
&=\left(d_{s 4}^{15}-d_{15}^{15}\right) \times 260+0.226 \times 1,0350-0.02 \\
&=\left(d_{s 4}^{15}-d_{a 15}^{15}\right) \times 260+0.21 \\
& \text { 今我々は } d_{s}^{15} \text { を } S, d_{a 15}^{15} \text { を } A \text { とすると } \\
& \quad E=(A-S) \times 260+0.21
\end{aligned}
$$

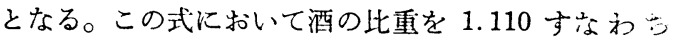
重ボーメ度で 14.3 の刚に扰いて平均値をもとめている のでここ以上のものはこの式の適用外になる。従って そのような濃度なもの（エキス 25 以上）については, 倍に肴釈して測定し，筑出され忠値を倍して真のエキス 量とすればよい嗼で，みりん類の場合はこれにかい当 する。 


$$
\begin{aligned}
& \text { 6-2 総酸（遊離酸） } \\
& 3 \text {-5による。 } \\
& \text { 6-6 アミノ酸 } \\
& \text { 3-6 による。 } \\
& \text { 6-7 メチルアルコール } \\
& \text { 6-4 の留液を用い } 301 \text { による。 }
\end{aligned}
$$

総酸, アミノ酸等はにより,メチル・アルコールにつ いては，6ー4の留液を用いるが，これについては後述 する。

$$
\text { 文献 }
$$

1 ）外池良三 : 本誌, $56,273(1961)$

2 ）川島宏 : 本誌, $55,569(1960)$

3 ）川島宏, 井上博 : 本誌, 52, 454(1957)

4 ）鹿又親, 山本宇三郎：本誌, 28, 21(1933)

\section{7-1 試料の採取}

びん詰は 2 本，缶詰は 3 ケ採取する。箱詰は適当な方法でビール瓶 2 本に採取し，密栓する。

7-2 性状

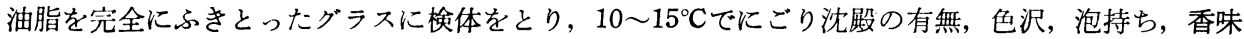
を調べる。

ビールの性状を見るためのグラスは，もちろん無色の あので，特に油脂類は完全にふきとってなければならな い。油脂は泡立ち，泡持ちに著しい覀影響を及ぼすから
である。温度を特に指定したのは，ビールがこの程度の 温度で飲まれるのが最良の状態であるからである。

$7-3$ ガス压

検体（びん詰のまま）をときどきふりながら $20{ }^{\circ} \mathrm{C}$ の水槽に 30 分保った後, びん内圧力計を王冠 にとりつけ針を突きさし軽くふって圧力 $\mathrm{kg} / \mathrm{cm}^{2}$ を読む。後, 王冠を抜いて温度を確める。 $20^{\circ} \mathrm{C}$ 以 外の温度の時は第 4 表により補正する。

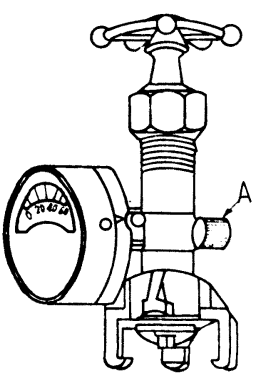

びん内厣力計
ビールは炭酸ガスを含み，び ん内には一定圧が保たれている 。ここでいらガス圧とは，びん 内圧力を測ることである。つま りびん内の水 1 容に対する炭酸 ガスの吸收溶解容を示すことに なる。压力計の構造は第 2 困の ようである。測定の際特に注意 することは，針と圧力計との間 からガスがもれることである。 そのためここにパッキングが設けられている。針が古く なるのも測定に讙差を生じ易い。

測定に当っては，まず $A$ を開いて内部の空気を除き， 次にこれを閉じて，所定り湓度になったびんの王冠に針
を突きさし，軽くふりながらゲージに表れる指針の示度 を読むのである。

温度は $20^{\circ} \mathrm{C}$ を保持することが必要である。止むを得 ないときは第 4 表の更正表を用いる。この表の使用法は たとえば $25^{\circ} \mathrm{C}$ でびん内圧 $3.50 \mathrm{~kg} / \mathrm{cm}^{2}$ であるとする と, 3.50 の縦列と $25^{\circ} \mathrm{C}$ の横列の交はるところの数字 3.3 を知り, $20^{\circ} \mathrm{C}$ の横列にある 3.3 を探し, この数字 の縦列にある気压欄の数字 $2.94 \mathrm{~kg} / \mathrm{cm}^{2}$ を見出すことが できる。

溶存している炭酸ガスの量をしりたい時は，この方法 では不適当で, 炭酸ガスを適当な方法で水酸化カリウム 等に吸収させ, この重量增加, あるいは残存したカリウ ムの量を測定する等の方法により，溶存炭酸ガス量をし ることがでさる1。

7-4 検体の調製（ガス拔き操作）

三角フラスコに $1 / 2$ 量の検体 $\left(20^{\circ} \mathrm{C}\right.$ 内外 $)$ をとり，手でフラスコのロを执さえて，手のひらに圧を感 じなくなるまで上下に振った後乾燥ろ紙で泡をろ別し, 密せんして貯える。

以下の試験にはこの検体を用いる。 
ビールの一般分析のためには, 溶存している炭酸ガ スを駆遂しなければならない。これがガス抜き操作であ るが，これにはいろいろの方法が提案されている。本法
は三角フラスコにビールを入れ，手でフラスコのロをお さえて上下に振るという方法をとった。二ケのビーカー を用意し，相互にあけか学るという方法もある。

\section{7 -5 比重}

検体をシリンダーにとり，此重浮ひょうを用い，15Cにおいてその示度を読み，比重とする。 注 $3-3(1) \sim(3)$ 注参照のこと。

ビールの比重は, 今迄の酒類と異り, 比重浮ひょうを

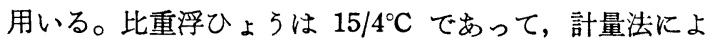
れば，物質の質量とその物質と同一の体積を有し，かつ 圧力 1,03250 バールの下に抢ける純粋の水の質量との 比となっている。単位は無名数である。

検定公差, 使用公差は次表の通りである。

もちろん孚ひょらであるから，その取扱いについては

$\begin{array}{clll} & 1 \text { 目盛の值 } & \text { 梌定公差 } & \text { 使用公差 } \\ \text { 比重 } 0.0002 \text { 以下 } & 0.0005 & 0.0005 \\ \prime \prime & 0.002 \text { 以下 } & 0.002 & 0.002 \\ \prime \prime & 0.005 \text { 以下 } & 0.005 & 0.005 \\ \prime \prime & 0.005 \text { こえるとき } & 0.01 & 0.01\end{array}$

$3-3$ 注 $(1) \sim(3)$, 前々回の解説を参照されたい。温 度補正表がないので, $15^{\circ} \mathrm{C}$ 測定する。

$$
\begin{gathered}
\text { 7-6 アルコール分 } \\
\text { 3-4による。 } \\
7-7 \text { エキス分 }
\end{gathered}
$$

次式によって算出する。

$$
E=(S-A) \times 260+0.21 \text { (小数点以下 } 2 \text { 位を四拾五入) }
$$

ただし $E$ エキス分, $S$ は比重, $A$ はアルコール分度数を第 5 表により比重 $\left(15 / 15^{\circ} \mathrm{C}\right)$ に換算したもの。

エキス分の算出式については, みりんの項を参照のこ

用いることができる。

と。この場合は原液を測定しているので基本式をその儘

$$
\begin{aligned}
& 7-8 \text { 総 酸 } \\
& \text { 7-8-1 試 薬 } \\
& \mathrm{N} / 10 \text { 水酸化ナトリウム溶液： } 3-5-1 \text { 亿よる。 } \\
& \text { フェノールフタレイン指示薬：3-6ー1 汇よる。 }
\end{aligned}
$$

7-8-2 試験操作

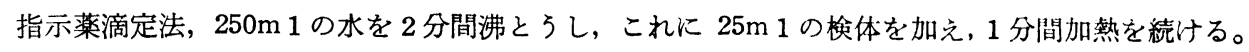
この際, 火力を調節して, 最後の 30 秒間再び沸騰するよ5にする。 5 分間放固後, 室温まで急冷し, フェノールフタレイン指示薬滴数を加え, N/10 水酸化ナトリウム溶液で, 淡桃仙に㲺るまでの滴定 $\mathrm{m} l$ 数を $a$ とする。

$$
\text { 酸度 }=a \times F \times 0.4 \text { (小数点以下 } 2 \text { 位を四拾五入) }
$$

電気滴定法, 検体 $50 \mathrm{ml}$ を $100 \mathrm{~m} l$ 容ビーカーにとり 1 分間軽く沸騰させた後室温にまで急冷し, 自動電位滴定装置を用いて $\mathrm{N} / 10$ 水酸化ナトリウム溶液で $\mathrm{pH} 8.2$ となるまで滴定する。この滴定 $\mathrm{m} l$ 数を $a$ とすれば酸度は次式によってもとめられる。

酸度 $=a \times F \times 0.2$ (小数点以下 2 位を四唅五入)

ビールに含まれる有機酸類も,もちろん単一ではない。 この場合は総酸を滴定するだ汁で十分である。試験操作 は指示薬を用いる普通の滴定法と, 濃色ビールを考虑し て電位差滴定法を併用することにした。

\section{指示薬滴定法}

前処理の検体の沸騰は, さらに残存する炭酸ガスを駆 遂するためである。10 倍に希釈してあるので, 普通の 淡色ビールかはこの方法で終末点も明らかである。検体
$10 \mathrm{ml}$ に対する $\mathrm{N} / 10$ 水酸化ナトリウムの滴定 $\mathrm{m} l$ 数で 表わすのを原則とした。

\section{奄気滴定法12)384)}

検体が濃色の場合は, 指示薬滴定では正確に終末点が つかめない。このため電気滴定法（電位滴定法）が用い られる。

一般に滴定液中に浸した 2 つの電極の間の電位差を測 定し, その急変する点から滴定の終末点をもとめる方法 


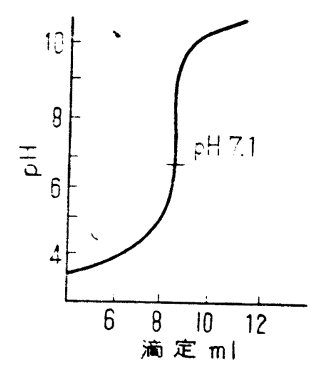

滴定曲楾
を電位滴定法と名づけるこ の場命は中和滴定であるから， 中和谪㳬の終术点は $\mathrm{pH}$ が念

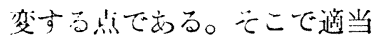
な電極の緗风合せを用いて $\mathrm{pH}$ 又はそれに比例した電位 を測定し，第 3 㘠のように横 軸に滴定 $\mathrm{m} l$ 数, 縦軸に $\mathrm{pH}$ をとるいわゆる滴定曲線を作 因すれば，容易にしか子正確 に終末点の判定が可能である。現在広く用いられている のはガラス電極の組合せであるが，決してこれに限った ことはない。またこの装置は自動電位滴定装瞋とある が, 自動でなければならない理由はないので，便利の点 と個人差の少い点から自動装渭を原則とした。
操作法 ビール究本法のように前処理をし， $\mathrm{pH} 7.0$ 附 近までは, 大体 $1.5 \mathrm{ml}$ ずつ, それから先は大体 $0.5 \mathrm{~m} l$ ずつ滴定して行き，本法で示された $\mathrm{pH} 8.2$ にまで滴定 する。自動式であれば始め $\mathrm{pH} 8.2$ に調節することによ って，自動的に滴下は停止する。マグネチックスターラ 一が普通はついているが，これがないような簡単なもの は，一定量添加毎に静かに摫找してもよい。

実際ビールの滴定曲線を書くと, 第 3 図のような標準 的に曲線を書かず，ゆるい傾斜になる。これはビールの 酸度が少いのと緩衝能が強いためであろ5。 $\mathrm{pH} 8.2$ と のしは, 我々が多くの実験の結果, 判定した数字で, A.O.A.C. むこの数字を採用している。

もちろん単なる本法のような滴定の場合は, 滴定曲線 は作図する必要はない。 $\mathrm{pH} 8.2$ と当量点を定めである からである。

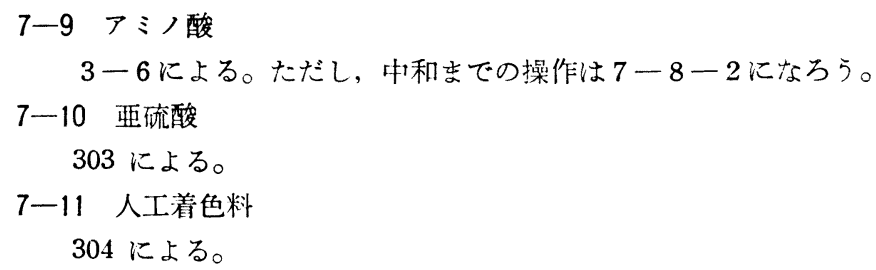

\section{文献}

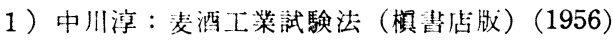

2) 日本分析化学会編：機器による化学分析 40 (九普 版) (1955)

3) 日本分析化学会近畿支部編：機器分析尖験法, 電 気容量分析 87 (植畫店版) (1957)
4) デラハイ著神原笪民訳：㙨器分析，37（共立版）

本稿を執筆するのに, 野白喜久雉, 小武山温之, 川島 宏, 井上博の四氏の御援助を得た。厚く感謝の意を表し たい。 